\title{
Reviewing S\&TS book reviews
}

\author{
Brit Ross Winthereik \\ brwi@itu.dk \\ Helen Verran \\ helenverran@gmail.com
}

With this issue we (Brit Ross Winthereik and Helen Verran) sign off as book review editors, handing over to Vincenzo Pavone. We expect that in the next few years Vincenzo will have as much fun and frustration as we did in doing this job, and wish him well. We take this opportunity to offer a brief look at the history of book reviews in this journal.

Some data:

- Since 2012 every issue of the journal has carried at least one book review text (with the exception of two special issue editions). Between 1998 and 2011 book reviews were irregular yet generally appeared more often as years went on.

- Eighty-six books in all have been reviewed in the history of the journal, with two books being given juxtaposed dual reviews. Thirtyeight of these books were monographs, the work of one or two authors, the rest being edited collections of papers. Reviews of events and exhibitions (three) were introduced in 2016

- Three authors had more than one of their publications reviewed: Bruno Latour (three) Steve Fuller (two), Helen Longino (two).
- Gender balance of authors and reviewers were as follows: authors and editors: 34 women and 101 men; reviewers: 44 women and 49 men

- The most popular book topics were: digital technologies, epistemology, STS as scholarly discipline, and science policy.

After we took over as book review editors we attempted to get more women as reviewers and particularly to get more students. We encouraged supervisors to work with their students on book reviews and to publish as dual authors of reviews. In the current academic atmosphere where time for writing that does not immediately lead to any 'points'/product is difficult to find, we were keen to highlight - especially to young scholars - that book reviewing for S\&TS do 'count' as they can be listed as publications on a developing CV.

We favoured reviews of monographs since we feel that edited collections are both difficult to review and even more difficult to review well. This attitude became harder and harder to sustain as fewer and fewer monographs are being published. In years past $\mathrm{PhD}$ theses often found publication in the form of monographs, something that is now becoming quite rare.

Table 1. Book reviews per year

\begin{tabular}{|c|c|c|c|c|c|c|c|c|c|c|c|c|c|c|c|c|c|}
\hline 1998 & 2002 & 2003 & 2004 & 2005 & 2006 & 2007 & 2008 & 2009 & 2010 & 2011 & 2012 & 2013 & 2014 & 2015 & 2016 & 2017 & 2018 \\
\hline 2 & 2 & 2 & 5 & 5 & 6 & 5 & 2 & 4 & 3 & 1 & 3 & 5 & 6 & 7 & 12 & 11 & 4 \\
\hline
\end{tabular}


A new phenomenon that has emerged over the past year or two has been the increasing difficulty of getting publishers to actually supply books for review other than the books they themselves like to see reviewed. As one publisher noted in confidence, increasingly publishing houses regard scholarly journals as competitors, especially open access journals. And publishers nowadays avoid investing in run-of-the mill edited collections of papers that arise in conferences, leaving that to the proliferating numbers of special interest journals only too willing to publish special interest editions.

In an attempt to encourage student book reviewers, a year or so ago we attempted to invent a new ritual in association with EASST meetings. We encouraged all those students who had been awarded EASST scholarships funding their attendance at the conference to accompany Brit around the press displays to choose a book for subsequent reviewing in S\&TS. Unfortunately, there was little enthusiasm shown for this proposal and not one review has since been submitted. We had more success in interesting young scholars to review exhibitions and events however and hope this interest expands.

When it comes to publishing STS books it is particularly gratifying to note the emergence of the innovative Mattering Press, a press specialising in publishing books adopting STS approaches to analysis. Beginning as a graduate student co-operative at Lancaster University in the UK, Mattering Press has emerged as a new type of practitioner led scholarly institution. The attitudes fostered amongst a group of cooperatively minded students now pervades the editing processes with authors supported to produce the best book they are capable of, while remaining within the remit of the press as an STS press.

So, what were our hopes as we took over the task of eliciting and supporting the production of reviews of books, exhibitions and events for publication in S\&TS? Of course, we expected scholarly reviews of rather than summary or opinion reviews such as you might find in newspapers or literary magazines. This was clearly news to some enthusiastic authors. This is one reason that we encouraged prospective reviewers, book authors, and publishers to contact us directly to discuss the prospect of a review. Encouraging direct submis- sion of book review texts to the journal can create a lot of unnecessary work.

What characterises a scholarly book review, and are scholarly reviews of STS books different than reviews of say philosophy, sociology, or anthropology books? Adequacy as a scholarly text is not what is at issue in a book review in a scholarly journal, given that 'quality control' is more the task of the sponsoring institutions and organisations. In this sense a book review is quite different than a review of an article for publication in a journal.

A scholar carries a sense of the several originary moments in a scholarly tradition from which analytic currents remain strong, and which might carry practitioners into generative futures at any given point in time. Given that future prospects for analytic traditions are always variously difficult prospects, having a general sense of possible futures can often help to make a book review interesting. For example, humanities and humanist social sciences scholars are increasingly voicing concerns that funders and students are abandoning Hermesian interpretive disciplines in favour of income-earning Apollonian disciplines that focus on 'useful' knowledge'. Since STS often sees itself as a nexus between these, that can be a way of locating a review that takes account of general scholarly issues. In STS, generative transgression of disciplinary boundaries is generally encouraged, often in contrast to other disciplines, where disciplinary boundaries are often policed in book reviews. Having a sense of what is at stake in disciplinary geographies is another means of making an STS book review interesting.

Of course, the ideal of publishing reviews by informed and thoughtful reviewers is not always, or perhaps often, achieved. This is complicated when we go out of our way to encourage students to undertake reviews. Yet even a beginning reviewer can ask where does this publication sit in the streams of analytic developments that I understand as constituting my discipline? And asking how does the reviewer locate him or herself in those streams, is exactly the challenge many students need.

In concluding we thank those authors, editors and reviewers who have helped create such a lively European STS scene in the past few years. Let us urge you as STS practitioners to keep writing both books and book reviews. 